\title{
Evaluation of Clinical and Demographical Characteristics of the Patients who Admitted to the Pediatric Emergency Department of a University Hospital
}

\author{
Esra Türe1, Erdal Erarslan², Abdullah Yazar1, () Fatih Akın1, (1) Dursun Odabaş1
}

${ }^{1}$ Department of Pediatric Emergency, Necmettin Erbakan University Meram Faculty of Medicine, Konya, Turkey

${ }^{2}$ Department of Pediatrics, Necmettin Erbakan University Meram Faculty of Medicine, Konya, Turkey

\begin{abstract}
Introduction: This study aims to evaluate the admissions to our pediatric emergency department, the diagnoses, the followups and treatments, contributing to plannings to be organized for timely and appropriate interventions.

Methods: In this study, 46756 patients who admitted to the pediatric emergency department of our hospital as an outpatient or via ambulance were included to be evaluated retrospectively by age range, gender, time of admission, frequency of admissions by months, the complaint of emergency department admission, the diagnosis made and whether they were hospitalized in an inpatient ward.

Results: In this study, 54\% of the patients were male and the rest of the patients were female. Evaluated by seasons, it was determined that the maximum number of admissions, in descending order, were in winter and spring months, and the minimum number of admissions, however, were in summer and autumn months. During the day, the busiest time of the pediatric emergency department was between 16:00 - 00:00. The most commonly made diagnosis in the pediatric emergency department in all months during the whole year was determined to be upper respiratory tract infection (34.9\%, n: 16060), followed by lower respiratory tract infections with a rate of 19.5\%. Among all patients, the number of cases for which a forensic report was issued, however, was determined to be $1.5 \%$. The hospitalization rate of all patients was determined to be $10.7 \% .3099$ (61.8\%) of a total of 5013 hospitalized patients were hospitalized in the pediatric emergency department observation unit, where their treatments were completed.

Discussion and Conclusion: Pediatric emergency departments, which will serve under appropriate conditions and opportunities, by which unnecessary admissions and hospitalizations will be reduced, and in which shorter observations will be made, would be able to provide services of better quality, reduce the number of unnecessary tests and allow effective intervention.

Keywords: Child; emergency patient; observation; triage.
\end{abstract}

$T$ he term "emergency" is defined as unusual events that occur suddenly, endanger life and/or impair the quality of life and as events that cannot be resolved in a short time by patients' relatives. Child emergency services are the clinics where intense stress is experienced concerning both the applicant patient and the physician, nurse and other healthcare professionals working in the emergency room. Striving to cope with sudden health problems may sometimes create an environment of turmoil in the emergency room. The patient selection system that does not

Correspondence (İletişim): Esra Türe, M.D. Necmettin Erbakan Universitesi Meram Tip Fakultesi, Cocuk Acil Bilim Dali, Konya, Turkey Phone (Telefon): +90 5056343290 E-mail (E-posta): dresrature@hotmail.com 
process well and that the concept of emergency is not fully understood may further increase the existing turmoil environment and may cause delays in the detection and intervention to the real emergency patient ${ }^{[1]}$.

It is estimated that the number of patients applying to emergency departments annually in our country is close to 100 million and $25 \%$ of this number is the childhood age group. Since more than $80 \%$ of the total mortality in childhood is due to acute emergencies, early recognition of high-risk patients will significantly reduce morbidity and mortality ${ }^{[2]}$. For this reason, physicians who are obliged to take care of emergency pediatric patients should be trained and experienced physicians who know how to interfere with children's emergency diseases and can determine the priorities correctly.

Of the patients who apply to pediatric emergency clinics, $60 \%$ are real emergency patients and $30 \%$ are non-emergency patients ${ }^{[3]}$. The increasing number of patients who are not emergency cases, on the one hand, prevents service to real emergency cases, and on the other hand, decreases the quality of service delivery and increases costs. Patients apply to the emergency services of the hospitals instead of primary healthcare services for many reasons, such as getting immediate health service, being able to benefit from the laboratory facilities quickly, the feature of social security, transportation status, working hours of parents and believing that emergency services are more equipped and sufficient ${ }^{[4]}$.

Our study aims to contribute to the effective emergency plan by examining all applications made to the pediatric emergency clinic of our hospital according to the diagnosis, treatment and epidemiological features of the patients.

\section{Materials and Methods}

Patients under the age of 17, who applied to the Pediatric Emergency Clinic between September 1, 2016, and August 31,2017 , transferred with ambulances or on an outpatient basis, were included in our study. After the approval of the ethics committee to conduct this study, patient information, emergency polyclinic record books, hospital archive files and hospital automation system data were analyzed retrospectively and recorded. Patients were divided into four groups according to their age groups, such as between 0-5 years, 5-10 years, 11-15 years, and $>15$ years. The diagnosis, age, sex, application time, application hour, International Disease Coding System (ICD-10) codes used, forensic cases, the time spent in the emergency room and the services the patients were hospitalized, were recorded.
Based on the data obtained, the distribution of patients by diagnosis, sex, age groups, months of application, seasons and time intervals were examined.

\section{Statistical Analysis}

The data obtained during this research were recorded using the MS Excel computer program. Statistical analysis of this study was carried out using Statistical Package for the Social Sciences (SPSS) for Windows version 20.0 package program. Descriptive analyses were used to analyze the distribution and frequency of the data, Chi-Square tests were used to compare two independent groups in frequency data, and multi-cell Chi-Square tests were used to compare three and more groups in frequency data. The significance level was accepted as $<0.05$ in all statistical analyses.

\section{Results}

This study included 46756 patients aged between 0-17 years, who applied to the Pediatric Emergency Clinic. When the distribution of all patients by sex was examined, it was determined that $54 \%(n=25113)$ were male and $46 \%$ $(n=21643)$ were female; no statistical significance was found concerning distribution by sex $(p>0.05)$. When the distribution of the patients by age range was examined, it was seen that patients under five years of age $(n=21585$, 46.2\%) applied at most with a statistical significance $(p=0.001)$.

When the distribution of the patients according to the seasons was examined, the highest number of applications were found to be in the winter season $(n=12847 ; 28 \%)$ and this was followed by the applications in autumn, spring and summer seasons, and when the distribution by months was analyzed, the highest number of applications were seen in January $(n=3872)$ and February $(n=3881)$. When examined according to the application time during the day, the maximum numbers were was determined between 16:00-00:00 $(n=26457 ; 56.5 \%)$ and the minimum number of applications was seen between 00:00 and 08:00 at night (Fig. 1). It was observed that the peak hours in pediatric emergency service was between 19:00 and 22:00 during the day (Fig. 2). There was no statistically significant difference regarding the patients' distribution according to seasons, months and application time $(p>0.05)$.

When all patients admitted to the pediatric emergency unit were examined according to the diagnosis and application complaints, a total of 70 different diagnoses were seen, and the most common diagnosis was upper respiratory tract infection (URTI) ( $n=16060 ; 34.9 \%)$ with statistically signifi- 
cance $(p=0.001)$. Distribution of diagnoses by sex is shown in Table 1, and the distribution of diagnoses by age groups is shown in Table 2.

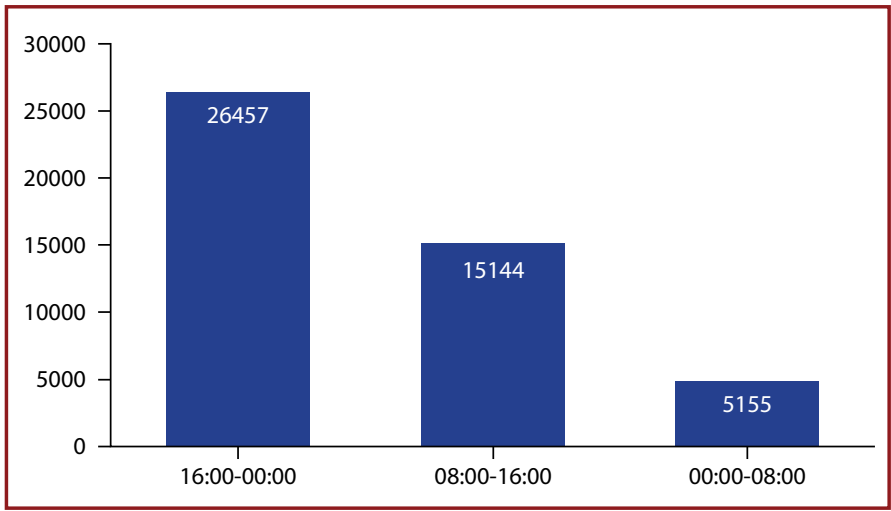

Figure 1. Distribution of patients according to the time of application to the emergency clinic.

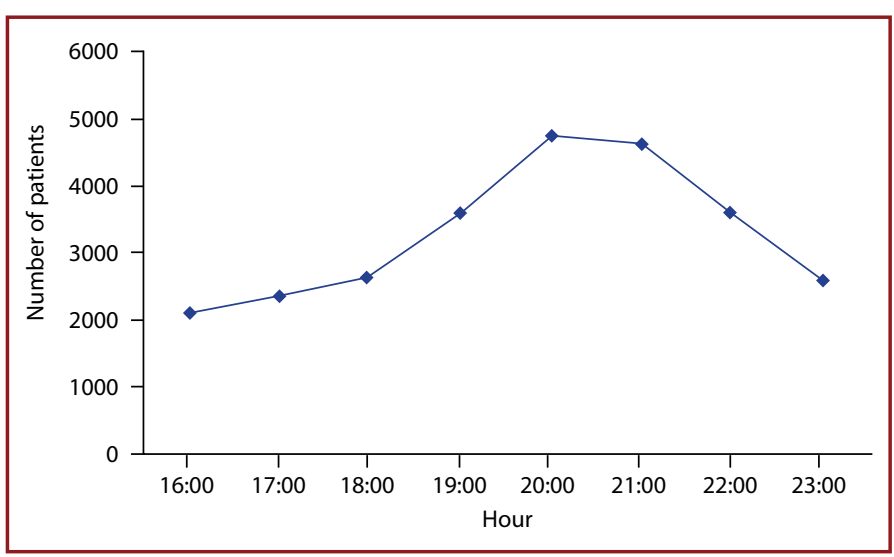

Figure 2. Distribution of cases by time during the day.
Of all applications, 709 (1.5\%) were found to be forensic cases. It was observed that $392(55.2 \%)$ of forensic cases were statistically significantly below the age of $5(p=0.01)$. The distribution of forensic cases by sex is shown in Table 3 . Of the 46756 patients who applied to the pediatric emergency service, 5013 (10.7\%) were hospitalized in the pediatric emergency department observation unit and other pediatric or pediatric surgery services. The distribution of the patients, according to their hospitalization units, is shown in Figure 3. It was determined that $61.8 \%(n=3099)$ of the 5013 patients hospitalized were statistically significant the most were the cases hospitalized in the emergency service observation unit, and their treatment was completed here $(p=0.001)$.

When only patients who were hospitalized in a pediatric

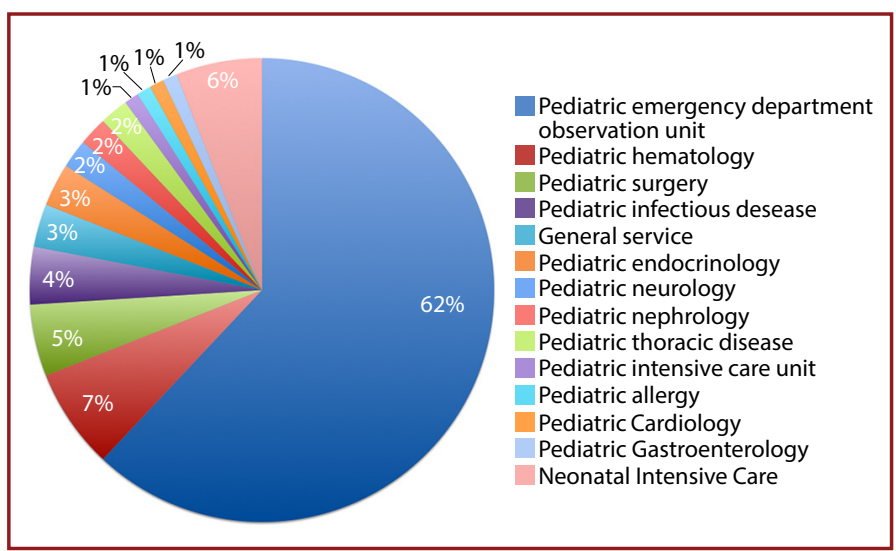

Figure 3. The distribution of patients according to their hospitalization units as referral from the emergency department.

Table 1. Distribution of the most common diagnosis and/or reasons for application by sex

\begin{tabular}{|c|c|c|c|c|c|c|c|}
\hline \multirow[t]{2}{*}{ Diagnosis } & \multicolumn{2}{|c|}{ Female } & \multicolumn{2}{|c|}{ Male } & \multicolumn{2}{|c|}{ Total } & \multirow[t]{2}{*}{$\mathbf{p}$} \\
\hline & $\mathbf{n}$ & $\%$ & $\mathbf{n}$ & $\%$ & $\mathbf{n}$ & $\%$ & \\
\hline URTI & 7473 & 46.5 & 8587 & 53.5 & 16060 & 34.9 & $>0.05$ \\
\hline A. bronchiolitis & 1683 & 42.2 & 2403 & 58.8 & 4086 & 8.2 & $>0.05$ \\
\hline Nausea- vomiting & 2022 & 46.2 & 2350 & 53.8 & 4372 & 9.5 & $>0.05$ \\
\hline Pneumonia (LRTI) & 1343 & 40.8 & 1944 & 59.2 & 3287 & 7.1 & $>0.05$ \\
\hline Urinary infection & 1244 & 52.0 & 1148 & 48.0 & 2392 & 5.2 & $>0.05$ \\
\hline Acute gastroenteritis & 1187 & 53.2 & 1043 & 46.8 & 2230 & 4.8 & $>0.05$ \\
\hline Rash disease & 671 & 45.8 & 792 & 54.2 & 1463 & 3.2 & $>0.05$ \\
\hline Asthma- Acute bronchitis & 910 & 56.2 & 710 & 43.8 & 1620 & 3.4 & $>0.05$ \\
\hline Epilepsy & 384 & 46.7 & 437 & 53.3 & 821 & 1.8 & $>0.05$ \\
\hline Other & & & & & 6193 & 13.2 & \\
\hline Total & & & & & 46756 & 100.0 & \\
\hline
\end{tabular}


Table 2. Distribution of the most common diagnosis and/or reasons for application by age range

\begin{tabular}{|c|c|c|c|c|c|c|c|c|c|c|}
\hline Diagnosis & \multicolumn{2}{|c|}{$<5$ years } & \multicolumn{2}{|c|}{ 5-10 years } & \multicolumn{2}{|c|}{ 11-15 years } & \multicolumn{2}{|c|}{$>15$ years } & Total & $\mathbf{p}$ \\
\hline URTI & 7213 & 44.9 & 5263 & 32.7 & 2635 & 16.4 & 949 & 5.9 & 16060 & 0.001 \\
\hline A. bronchiolitis & 4086 & 100 & 0 & 0 & 0 & 0 & 0 & 0 & 4086 & 0.001 \\
\hline Nausea-vomiting & 1975 & 45.1 & 1426 & 32.7 & 623 & 14.3 & 348 & 7.9 & 4372 & 0.001 \\
\hline Pneumonia (LRTI) & 1080 & 32.9 & 1111 & 33.8 & 590 & 17.9 & 506 & 15.4 & 3287 & 0.01 \\
\hline Urinary infection & 987 & 41.2 & 912 & 38.2 & 327 & 13.7 & 166 & 6.9 & 2392 & 0.001 \\
\hline Acute gastroenteritis & 775 & 34.7 & 1007 & 45.1 & 276 & 12.4 & 172 & 7.8 & 2230 & 0.01 \\
\hline Rash disease & 686 & 46.8 & 456 & 31.1 & 217 & 14.9 & 104 & 7.2 & 1463 & $>0.05$ \\
\hline Asthma- Acute bronchitis & 206 & 12.7 & 496 & 30.6 & 616 & 38.0 & 302 & 18.7 & 1620 & $>0.05$ \\
\hline Epilepsy & 330 & 40.1 & 275 & 33.4 & 137 & 16.7 & 79 & 9.8 & 821 & 0.001 \\
\hline Other & & & & & & & & & 6193 & \\
\hline Total & & & & & & & & & 46756 & \\
\hline
\end{tabular}

Table 3. Distribution of the diagnoses of all forensic cases by sex

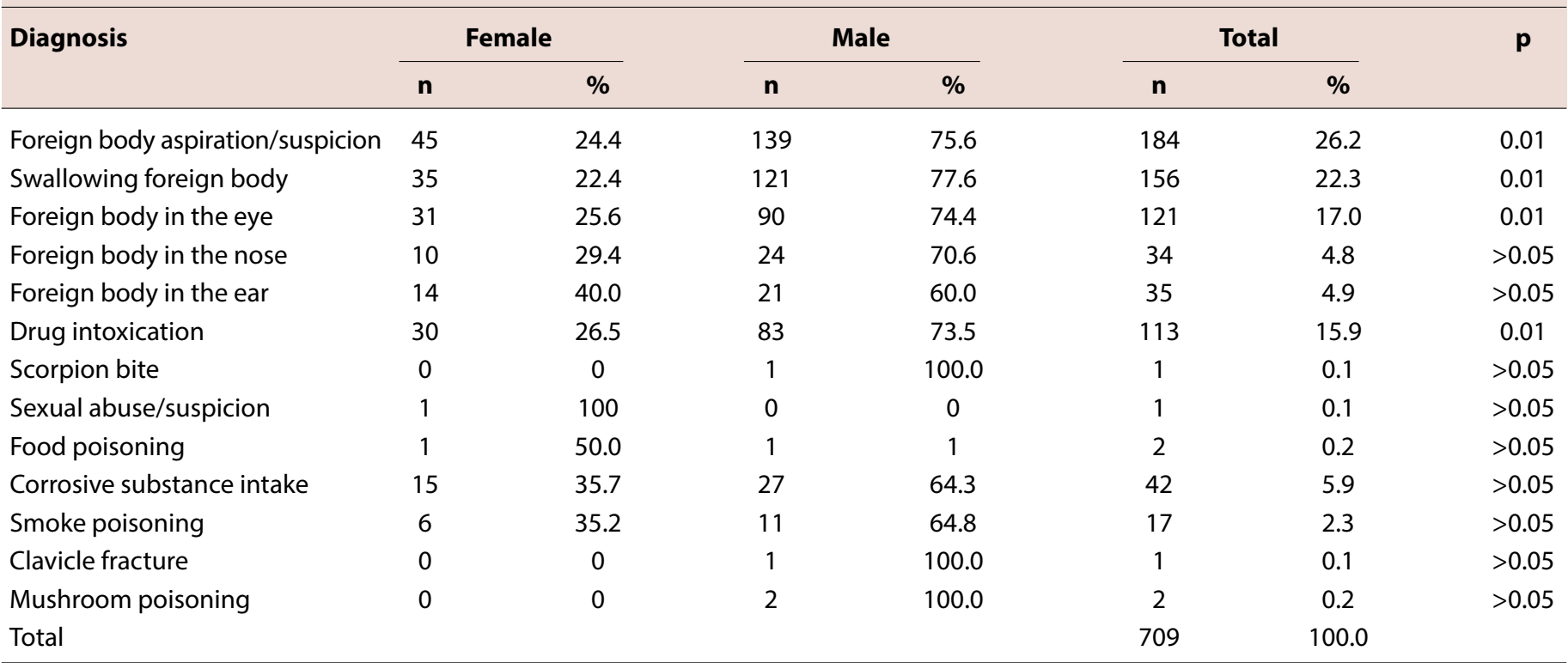

emergency service observation unit were examined, 59\% of the 3099 patients $(n=1830)$ were statistically significantly found to be the most often under the age of five ( $p=0.02)$. When the distribution of these patients by sex was examined, it was determined that $57.6 \%(n=1787)$ were male with a statistical significance $(p=0.01)$. It was found that the patients who were diagnosed with respiratory system diseases in the pediatric emergency room were followed most frequently, followed by the patients with the diseases of the gastrointestinal tract and the patients who were diagnosed with neurological disease due to seizures for the first time and/or previous seizures. When the patients who were hospitalized in the emergency observation unit and whose treatment were completed here, were evaluated according to the length of hospitalization, it was observed that 2568 $(82.8 \%)$ of 3099 patients were observed for 24 hours or less, and 531 (17.2\%) were followed up for more than 24 hours in the pediatric emergency service. The average length of hospitalization of the patients in the pediatric emergency unit was found to be 1.4 days/patient, and the patient with the longest hospitalization period in the pediatric emergency observation unit was found to be 84 days. 
It was determined that a total of 733 (1.56\%) patients applied to the pediatric emergency room for intramuscular or intravenous injection, while $358(0.76 \%)$ patients were referred from other departments for examination purposes only.

It was determined that within one year, three $(0.006 \%)$ patients who admitted to the pediatric emergency unit were accepted at exitus status, and $41(0.08 \%)$ patients were found to be at exitus status after admitting to the emergency room and referred to other services.

\section{Conclusion}

Sufficient physical conditions, medical equipment and experienced medical staff are required to provide effective, appropriate and timely pediatric emergency medical services. Recording pediatric emergency room data, evaluating these data at regular intervals, making arrangements in accordance with this assessment will provide better service to patients, effective use of resources, and increase patient and employee satisfaction. For this purpose, the development of plans for pediatric emergency patients and services and scientific studies on this subject should be supported. Making timely and appropriate interventions for pediatric emergency patients should aim to eliminate the difficult-to-repair material and moral damages, time and labor losses that arise from disability and diseases ${ }^{[2]}$. In our study, as a tertiary university hospital, it was aimed to determine the clinical and demographic features of all patients who applied to our pediatric emergency room in the previous year, to contribute to the data of our country on this issue, to help with measures and restructuring efforts.

In different studies conducted in our country, it was determined that more than half of the patients who applied to the pediatric emergency department were male ${ }^{[5,6]}$. In our study, $54 \%$ of the patients were male, consistent with the literature. Because clinical situations requiring urgent intervention in children are more in male can be explained by that the boys are more active, they have more contact with the external factors and the environment and are more curious.

In a study where applications to pediatric emergency departments were evaluated by months, it was found that the highest number of applications were made in December and January, and the minimum number of applications was made in August ${ }^{[7]}$. Similarly, it was seen in the studies that the season with the highest number of pediatric emergency patient applications was winter ${ }^{[4,8]}$. In our study, the highest number of applications were also in winter and spring, respectively, similar to the literature, and the least number of the application of patients was determined in
June. We think that the reason why child emergency departments are busier in winter months may be related to spending more time in crowded and poorly ventilated environments (school, kindergarten) and inadequate home-warming environment, especially in regions with low socioeconomic and educational levels.

Applications to the emergency departments are made mostly at off-hours. In a study conducted in 2014, the detection of pediatric patients applying to the emergency department with a high rate of $60.9 \%$ at most between $16: 00$ 00:00 and at least between 00:00-08:00, supports this ${ }^{[6]}$. Similarly, in our study, we found that $56.5 \%$ of patients applied to the emergency room between 16:00-00:00 and $11 \%$ after midnight. It is thought that factors, such as parents working when pediatric outpatient clinics are open, knowing that they receive faster service in the emergency department, patients and their relatives not wanting to wait in the outpatient clinic queue, although this fact is not certain, the laboratory examinations requested from the emergency department resulting in a shorter time and disruption of the outpatient appointment systems may be effective in this situation.

In a multicentre study that examined patients who applied to pediatric departments in five years in our country, it was determined that $57.5 \%$ of the patients were between $0-2$ years of age, $24 \%$ between the ages of $2-4$ years and $15.4 \%$ were between the ages $5-10^{[7]}$. We also found that $46.2 \%$ of the patients were statistically significantly less than five years old, similar to other studies $(p=0.01)$. The factors that affect this result are that the parents cannot tolerate the patient's restlessness and agitation for a long time, taking complaints more seriously in this age group, and the general condition of the patient that can show changes in a short time.

In studies conducted, the most common reason for applying to emergencies was determined to have consisted of complaints that arise from URTI, such as fever, cough and runny nose ${ }^{[4,6]}$. In a study, it was found that the most common diagnosis in the pediatric emergency department was acute URTI (55.7\%), followed by patients diagnosed with acute gastroenteritis (AGE) (11.4\%) and acute asthma attack (8\%), respectively ${ }^{[9]}$. In our study, the patients who applied to the pediatric emergency department of our hospital were found to be the most frequently diagnosed with URTI $(p=0.01)$. We think that the low rates of AGE in our study were due to the misdiagnosis of some of these cases as nausea and vomiting in the ICD coding system.

In childhood, accidents are among the most frequent pre- 
ventable health problems. Every patient admitted to the hospital for reasons, such as assault, all kinds of tool injuries, burns, electric shock, torture and ill-treatment, child abuse, poisoning, and all kinds of suicide attempts are of forensic nature ${ }^{[10]}$. In the studies conducted in our country, the rate of pediatric forensic cases varied between $1.5 \%$ and $7.4 \%$ among all patients who applied to emergency departments, and these cases were mostly male patients ${ }^{[11-14]}$. In our study, the rate of forensic cases was found to be $1.5 \%$ $(\mathrm{n}=709)$ among all patients. Even though it was not statistically significant, it was observed that male patients had higher rates among forensic cases, with $54.1 \%$. Although our hospital is a regional hospital, we can link the low rate of forensic cases to the trauma patients to be not primarily considered and taken care of in our pediatric emergency department.

In a study evaluating poisoning cases that applied to the pediatric emergency department of a tertiary hospital, it has been determined that the most common reason of application is poisoning with medicines, followed by exposure to corrosive substances, carbon monoxide poisoning, scorpion and snake bites, hydrocarbons and pesticide exposure, respectively ${ }^{[15]}$. In another study evaluating the poisoning cases that applied to the pediatric emergency department in our country, the reasons for application of the patients were investigated by years, and it was determined that poisoning with drugs was in the first place between 2000-2001. Poisoning with agricultural-industrial factors was in the first place between $2002-2003^{[16]}$. Similarly, in a study of all forensic cases conducted between 2015 and 2016 in our clinic, it was determined that the cases of poisoning were in the first place and poisoning was seen most frequently with drugs ${ }^{[17]}$. In another study conducted in our country, when the poisoning cases were examined according to age groups, they were most frequently found between the ages of $0-4^{[18]}$. In another study in which poisoning cases were examined, it was determined that poisonings with drugs were at the forefront, single drug exposure was detected in the vast majority of patients, and the most frequent drugs exposed were found to belong to the analgesic and antipyretic drug groups ${ }^{[19]}$.

$10.7 \%$ of the 46756 patients who applied to the pediatric emergency clinic of our hospital continued their treatment by hospitalization in pediatric services and pediatric surgery services. In the studies carried out in our country, the rate of referral from the pediatric emergency departments to hospitalization in pediatric inpatient services varies between $1.6 \%$ and $10 \%$, according to the centers ${ }^{[4,6,7]}$. Due to the presence of all pediatric departments in our hospital, except for pediatric gastroenterology, patients are accepted from hospitals in the center, districts of Konya and even from surrounding cities. At the same time, our hospital is easily accessible as it is very close to the city center. Sometimes, parents can remove their patients at their own request and bring them to the pediatric emergency while the patients are receiving treatment in other hospitals if the disease processes are prolonged. For all these reasons, although our hospital does not accept pediatric trauma patients, the rate of hospitalization to emergency services was found to be high in our study.

When inpatients were evaluated according to their hospitalized department, it was seen that the highest rate of hospitalization was in the pediatric emergency observation unit with a high rate of $61.8 \%(p=0.01)$. We can list the factors that led to this situation as our faculty is a regional hospital. Thus, the inpatient services cannot meet the demand, our hospital provides education and services in all pediatric disciplines, and the treatment of patients examined in other pediatric outpatient clinics starts in the pediatric emergency observation unit.

Data on how child emergency observation units are used are limited and studies in this area are few, which remained under-researched. Therefore, in our study, we aimed to determine which patients the emergency observation units are used, which are another option besides the inpatient services and to contribute to the effective working system of the emergency service. The findings of some diseases can mimic emergency situations. In such cases, starting treatment without observing the patient causes unnecessary treatment and prolonged hospital stay. A study conducted in our country shows that very few of the patients who applied to the child emergency department due to abdominal pain needed urgent surgery ${ }^{[20]}$. In studies involving adult patients, it has been shown that short-term follow-up of patients in observation units may prevent diagnostic errors $^{[21]}$.

In our study, when the patients who were hospitalized in the pediatric emergency observation unit were examined, it was seen that the patients were at most 0-5 years old with statistically significant $(59 \%)(p=0.01)$. This was followed by patients between 5-10 years old, 11-15 years old and over 15 years old. Although it was not statistically significant considering all age groups, it was determined that the majority of male patients were higher. Similarly, in a study conducted in our country, $54.6 \%$ of the patients who were followed up in the emergency observation units 
were male, and $45.4 \%$ were female ${ }^{[9]}$. In a study conducted in İmir in 2014, when the reasons for hospitalization of patients who were observed in emergency departments were evaluated according to the systems, it was determined that patients with diseases related to the respiratory system, gastrointestinal system and urinary system were taken under observation most frequently, respectively ${ }^{[4]}$. In our study, patients with respiratory and gastrointestinal system diseases were treated most frequently in the pediatric emergency observation unit in accordance with the literature. Unlike other studies, patients who were previously diagnosed or had seizures for the first time were in third place in the pediatric emergency observation unit according to the number of cases. This can be explained by the fact that our hospital serves as a pediatric neurology center in our region.

In a study conducted in our country examining the reasons for parents to apply to the child emergency, it was concluded that the level of parental anxiety increased the application to the hospital, and it was suggested that providing information about the diseases may decrease the unnecessary anxiety of the parents and thus may reduce the emergency room applications ${ }^{[22]}$. In another study conducted in our country, it was determined that patients used the hospital emergency room for non-emergency reasons that could be resolved in primary care services ${ }^{[23]}$. In a study examining the profile of the patients applying to a state hospital emergency department and the relevance of the applications, it was concluded that non-emergency patients increased the workload of the emergency department, educating and raising awareness of the patients and making first-line health services available, and correct, effective and feasible policies regarding the emergency services of the country, should be established ${ }^{[24]}$.

As a result, the majority of the patients who applied to the pediatric emergency department and hospitalization was decided as a result of their examination, were hospitalized in the observation unit and their treatment was completed and discharged; and this resulted in preventing unnecessary hospitalization in inpatient clinics, preventing a delay in diagnosis and treatment of suspicious cases as clinical findings, decreasing the length of hospital stay of patients and increasing patient satisfaction by discharging patients more quickly. However, these units where short-term observations of patients can be performed, play an effective role in preventing unnecessary investigations and loss of time by providing monitoring opportunity to follow up suspicious cases, in case they serve to appropriate patient population in appropriate conditions.
Ethics Committee Approval: Necmettin Erbakan University Meram Faculty of Medicine Ethics Committee (Approval number: 2017/1112).

Peer-review: Externally peer-reviewed.

Authorship Contributions: Concept: E.T., E.E., A.Y., F.A., D.O.; Design: E.T., E.E., A.Y., F.A., D.O.; Data Collection or Processing: E.T., E.E., A.Y.; Analysis or Interpretation: E.T., E.E., A.Y., F.A., D.O.; Literature Search: E.T., E.E.; Writing: E.T., E.E.

Conflict of Interest: None declared.

Financial Disclosure: The authors declared that this study received no financial support.

\section{References}

1. Brousseau DC, Mistry RD, Alessandrini EA. Methods of categorizing emergency department visit urgency: a survey of pediatric emergency medicine physicians. Pediatr Emerg Care 2006;22:635-9. [CrossRef]

2. Çocuk AcilTıp ve Yoğun Bakım Derneği. Türkiye'de ve Dünya'da Çocuk Acil Tıp Hizmetleri Mevcut Durum ve Öneriler. Available at: http://www.cayd.org.tr/gorseller/files/raporlar/TURKIYE ve_DUNYA_COCUK_ACIL.pdf. 2008.

3. Emergency Care for Children: Growing Pains. 1st ed. 2006, Washington DC: The National Academies Press. 2006. Available at: https://www.nap.edu/read/11655/chapter/1.

4. Anıl M, Anıl AB, Köse E, Akbay S, Helvacı M, Aksu N. Bir Eğitim ve Araştırma Hastanesi Çocuk Acil Servisi'ne Başvuran Hastaların Değerlendirilmesi. Çocuk Acil ve Yoğun Bakım Dergisi. 2014;1:65-71.

5. Ayvaz A, Güngör N, Topbaş M, Yıldızlar O, Çan E, Akkol N. Trabzon Sürmene Devlet Hastanesi acil polikliniğine başvuran çocuk hastaların özellikleri. Cumhuriyet Üniversitesi Tıp Fakültesi Dergisi 2007;29:156-62.

6. Yılmaz AA, Köksal AO, Özdemir O, Yılmaz Ş, Yıldız D, Koçak $M$, et al. Bir Eğitim Araştırma Hastanesi Çocuk Acil Kliniğine Başvuran Olguların Değerlendirilmesi. Türkiye Çocuk Hastalıkları Dergisi 2015;1:18-21.

7. Köksal AO, Köksal T, Yüksel S. Beş Yıllık Hasta Kayıtlarının Değerlendirildiği Çocuk Sağlığı ve Hastalıkları Merkezi Verileri ve Kayıt Sisteminin Önemi. Gaziosmanpaşa Üniversitesi Tıp Fakültesi Dergisi 2015;1:105-15.

8. Pileggi C, Raffaele G, Angelillo IF. Paediatric utilization of an emergency department in Italy. Eur J Public Health 2006;16:565-9. [CrossRef]

9. Derinöz O, Tunaoğlu FS. Çocuk acil gözlem birimlerinin çocuk hastalar için kullanımı: Bir üniversite hastanesinin izlenimleri Orijinal Araştırma. Turk Pediatri Ars 2007;42:61-4.

10. Sever M, Saz EU, Koşargelir M. Bir üçüncü basamak hastane acil servisine başvuran adli nitelikli çocuk hastaların değerlendirilmesi. Ulus Travma Acil Cerrahi Derg 2010;16:260-7.

11. Büken E, Yaşar ZF. Başkent Üniversitesi Ankara Hastanesi acil servisine başvuran adli nitelikteki çocuk olguların değerlendirilmesi. The Bulletin of Legal Medicine 2015;20:93-8.

12. Turla A, Aydın B. Ondokuz Mayıs Üniversitesi Tıp Fakültesi'ne 
Başvuran Adli Nitelikteki Çocuk 0-18 Yaş Olguların Değerlendirilmesi. The Bulletin of Legal Medicine 2007;12:106-11.

13. Korkmaz T, Erkol Z, Kahramansoy N. Acil Servise Gelen Pediatrik Adli Olguların Değerlendirilmesi: Retrospektif Bir Çalışma. Haseki Tıp Bulteni 2014;52:271-7. [CrossRef]

14. Yücel $A B$, Sütoluk $Z$, Yılmaz LH, Akbaba M, Aytaç N. Çukurova Üniversitesi Tıp Fakültesi Çocuk Acil Servisi'ne 2004 yılında başvuran ve adli vaka olarak kayıtlara geçen olguların değerlendirilmesi. The Bulletin of Legal Medicine 2005;10:90-5.

15. Eliaçık K, Kanık A, Karanfil Ö, Rastgel H, Metecan A, Oyman G, et al. An evaluation of the admissions to a tertiary hospital pediatric emergency department with intoxication. Smyrna Tıp Dergisi 2012;2:41-4.

16. Genç G, Saraç A, Ertan Ü. Çocuk hastanesi acil servisine başvuran zehirlenme olgularının değerlendirilmesi. Nobel Medicus 2007;3:18-22.

17. Yazar A, Akın F, Türe E, Odabaş D. Çocuk Acil Kliniğine Başvuran Adli Vakaların Değerlendirilmesi. Dicle Tıp Dergisi 2017;44:345-53. [CrossRef]

18. Özdemir A.A, Elgörmüş Y, Çağ Y. Acil Servise Gelen Adli Nite- likli Çocuk Olguların Değerlendirilmesi. Int J Basic Clin Med 2016;4:1-8

19. Yorulmaz A, Akbulut $H$, Yahya İ, Aktaş R, Emiroğlu HH, Peru $H$. Çocuk acil servisine zehirlenme nedeni ile başvuran olguların geriye dönük olarak değerlendirilmesi. J Pediatr Emerg Intensive Care Med 2017;4:96-103. [CrossRef]

20. Erkan T, Cam H, Ozkan HC, Kiray E, Erginoz E, Kutlu T, et al. Clinical spectrum of acute abdominal pain in Turkish pediatric patients: a prospective study. Pediatr Int 2004;46:325-9. [CrossRef]

21. Graff L, Radford MJ, Werne C. Probability of appendicitis before and after observation. Ann Emerg Med 1991;20:503-7.

22. Karakaş N. M, Özdemir B, Kılıç S, Akbulut Ö. Ebeveynleri Çocuk Acile Getiren Nedenler: 4 yıllık İzlem. Osmangazi Tıp Dergisi 2019;42:67-74. [CrossRef]

23. Boran $P$, Tokuç G, Çoban Büyükkalfa $D$, Taşkın B, Pişgin B. Çocuk Acil Servisine Başvuran Vakaların Değerlendirilmesi. Çocuk Dergisi 2008;8:114-6.

24. Köse $A$, Köse $B$, Öncü MR, Tuğrul F. Bir devlet hastanesi acil servisine başvuran hastaların profili ve başvurunun uygunluğu. Gaziantep Medical Journal 2011;17:57-62. [CrossRef] 